Design Options for Low-Conductivity Window Frames

N. Byars and D. Arasteh

October 1990

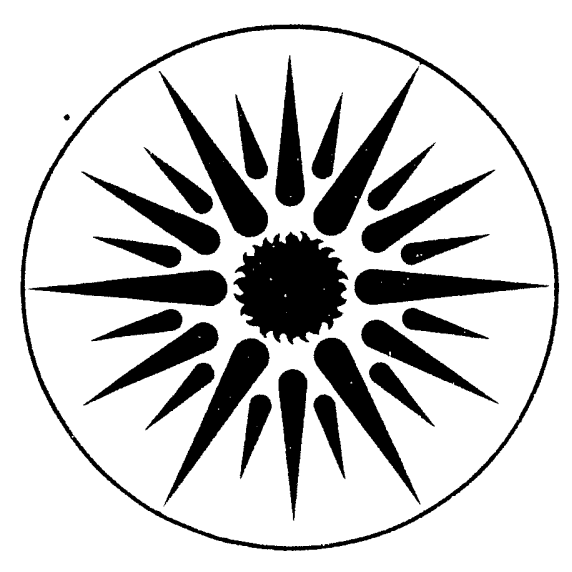

APPLIED SCIENCE DIVISION 


\section{DISCLAIMER}

This document was prepared as an account of work sponsored by the United States Government. Neither the United States Government nor any agency thereof, nor The Regents of the University of California, nor any of their employees, makes any warranty, express or implied, or assumes any legal liability or responsibility for the accuracy, completeness, or usefulness of any information, apparatus, product, or process disclosed, or represents that its use would not infringe privately owned rights. Reference herein to any specific commercial product, process, or service by its trade name, trademark, manufacturer, or otherwise, does not necessarily constitute or imply its endorsement, recommendation, or favoring by the United States Government or any agency thereof, or The Regents of the University of California. The views and opinions of authors expressed herein do not necessarily state or reflect those of the United States Government or any agency thereof or The Regents of the University of California and shall not be used for advertising or product endorsement purposes.

This report has been reproduced directly from the best available copy.

Available to DOE and DOE Contractors from the Office of Scientific and Technical Information P.O. Box 62, Oak Ridge, TN 37831

Prices available from (615) 576-8401, FTS 626-8401

Available to the public from the National Technical Information Service

U.S. Department of Commerce

5285 Port Royal Road, Springfield, VA 22161

Lawrence Berkeley Laboratory is an equal opportunity employer. 


\title{
Design Options for Low-Conductivity Window Frames
}

\author{
Nan Byars and Dariush Arasteh \\ Applied Science Division \\ Lawrence Berkeley Laboratory \\ University of California \\ Berkeley, California 94720
}

October 1990

This work was supported by the Assistant Secretary for Conservation and Renewable Energy, Office of Building Technologies, Building Systems and Materials Division of the U.S. Department of Energy under Contract No. DEAC03-76SF00098. Additional support was provided by the Residential Technology Section of the Bonneville Power Administration of the U.S. Department of Energy under Contract No. DE-AI79-86BP63401. 


\title{
Design Options for Low-Conductivity Window Frames \\ Nan Byars" and Dariush Arasteh \\ Applied Science Division \\ Lawrence Berkeley Laboratory \\ Berkeley, CA 94720
}

October 1990

\begin{abstract}
The window industry's commercialization of low-emissivity coatings and lowconductivity gas-filling over the past few years has helped to drastically reduce heat transfer rates through the glazed areas of windows. However, few changes have taken place in the design and construction of window frames and edges, leaving these elements to account for most of the heat transfer through today's state-of-theart windows. This paper presents design and material requirements for the manufacture of low-conductivity window frames obtained through the use of finite element computer modeling. Such frames will compliment and not degrade today's most energy-efficient insulated glass units.
\end{abstract}

\section{Introduction}

Advancements in energy efficient window design have accelerated rapidly over the last five years. With the use of low-E coatings and low conductivity gas fills, three layer insulated glass units can now achieve center-of-glass U-values as low as 0.10 $\mathrm{Btu} / \mathrm{hr}-\mathrm{ft}^{2}-\mathrm{F}[1,2], 60$ to $80 \%$ lower than conventional triple and double glazed units of the mid 1980's.

However, limiting heat transfer over the center-of-glass area (see Figure 1) is only part of the problem. Windows with center-of-glass U-values in the range of 0.10 $\mathrm{Btu} / \mathrm{hr}-\mathrm{ft}^{2}$-F but built with typical wood frames and conventional metal spacers have total window U-values between $0.15-0.25 \mathrm{Btu} / \mathrm{hr}-\mathrm{ft}^{2}-\mathrm{F}$. This performance degradation is due to the thermal bridging effects of the spacers and the higher $U$ values of the wood frames (typical wood frames have effective frame U-values in the range of $0.25-0.60 \mathrm{Btu} / \mathrm{hr}-\mathrm{ft}^{2}-\mathrm{F}$ ). The development of windows with total U-values in the range of $0.10 \mathrm{Btu} / \mathrm{hr}-\mathrm{ft}^{2}-\mathrm{F}$ requires the development of insulating spacer/edge systems and low-conductivity frames. Reducing heat transfer through the edge-ofglass areas with alternative (nonmetallic) spacer materials and designs is discussed in [3].

This paper provides information obtained through finite element modeling useful in the design and material selection of low-conductivity frames. Finite element modeling was used to predict the U-values for window frames with varying sash and jamb materials and designs. This paper does not address the structural

- Assistant Professor, Engineering Technology Department, California Polytechnic University, San Luis Obispo, CA. 
requirements or feasibility of designing and manufacturing of the frame configurations presented.

\section{Methodology}

ANSYS [4], a commercially available finite-element modeling program was used to perform a two-dimensional, steady state heat transfer analysis on a typical picture window frame. All simulations assumed an insulated glass center-of-glass U-value of $0.12 \mathrm{Btu} / \mathrm{hr}-\mathrm{ft}^{2}-\mathrm{F}$. Frame U-values were calculated for a variety of materials and designs.

We considered two possible approaches to developing insulating frames: "solid frames" and "clad frames." In both cases as shown in Figure 1, the frame consists of a sash and a jamb (representative of the jamb, sill, or header). Solid frames assume the conductivity of the jamb is constant throughout the jamb and conductivities of the sash are constant throughout the sash; conductivities of the jamb and sash are not always equal. Solid frames were analyzed by varying the conductivity of the jamb and sash as a percentage of the conductivity of wood; this simulates the possible performance of wood composites, structural foams, and other as yet undeveloped materials. Clad frames are comprised of a thin outer skin (i.e. vinyl or fiberglass) containing an inner insulating material. Clad frames were analyzed by varying the thickness and conductivity of the cladding and the conductivity of the fill material. Throughout this paper, unless otherwise noted, we assume the use of an insulating spacer/edge system.

Material conductivities assumed are shown in Table 1. Note that where two materials are used together with widely differing conductivities (i.e. clad frame), small differences $(10-25 \%)$ in the conductivity of one or both materials will not result in noticeable changes to the overall configuration.

Table 1: Material Conductivities

Material

Aluminum

Fiberglass

Insulating material (polystyrene)

Vinyl

Wood
Conductivity (Btu/hr-ft-F)

128.0

0.170

0.017

0.084

0.067 


\section{Results}

Figure 2 presents frame $U$-values for variations in jamb and sash conductivities for the "solid frame" model. Jamb and sash conductivities were varied as a percentage of the conductivity of wood to predict the relative effects of lower conductivity materials on frame performance. All simulations assume the use of an insulating spacer (a spacer made of an insulating material as defined in Table 1). Going from a wood jamb and sash to a frame with a conductivity $50 \%$ that of wood and a sash with a conductivity $10 \%$ that of wood, reduces the frame U-value from 0.26 to 0.10 $\mathrm{Btu} / \mathrm{hr}-\mathrm{ft}^{2}-\mathrm{F}$. Similar drops in frame U-values are achieved with conventional metal spacers (Table 2).

Table 2: Frame U-Values for Spacer Material Variations (Btu/hr-ft' $-\mathrm{F})$

Jamb/Sash

$\frac{\text { Spacer Material }}{\text { Aluminum }}$ Wood Insulation

Conductivities

$100 \% / 100 \%$ wood

0.36

0.28

0.26

$50 \% / 10 \%$ wood

0.14

0.11

0.10

Tables 3 and 4 show the effects of varying cladding thickness and fill materials on "clad frame" frame U-values. Table 3 presents results for models with sash conductivity variations with an all wood jamb. Drastically reducing the cladding thickness or material (i.e. from 0.08 to 0.04 inches thick or from fiberglass to vinyl) is not as significant as changing the fill from wood to a better ir.ulating material (the insulating material in Table 1). Once the fill is insulated, the cladding thickness and conductivity become important. Table 4 incorporates the effects of jamb and sash variations. Greater cladding thickness increases frame U-values slightly; the increase is greater for lower conductivity fill materials. Skin and fill material variations for both an aluminum spacer and an insulating spacer for a cladding thickness of 0.04 inches are shown. U-values for the insulating spacer are significantly lower than those for the aluminum spacer in all cases. 
Table 3: Frame U-Values for Sash Material and Skin Thickness Variations (Btu/hr- $\mathrm{ft}^{2}-\mathrm{F}$ )

All wood jamb, insulating spacer.

\section{Wood-Filled Sash Insulation-Filled Sash}

Vinyl Clad Sash

$0.04^{\prime \prime}$ Cladding

$0.08^{\text {" Cladding }}$

0.26

0.27

0.19

Fiberglass Clad Sash

$0.04^{\text {" Cladding }}$

$0.08^{n}$ Cladding

0.28

0.29

0.20

0.23

Table 4: Frame U-Values (Btu/hr-ft $\left.\mathrm{ft}^{2} \mathrm{~F}\right)$ for Sash \& Jamb Material and Cladding Thickness Variations. Spaces are either Aluminum (Al) or Insulated (In)

Vinyl Clad Sash

Wood-Filled Sash

Insulation-Filled Sash

0.04 " Cladding

Al spacer

0.37

0.27

0.19

In spacer

0.27

0.11

$0.08^{\prime \prime}$ Cladding

In spacer

0.14

Fiberglass Clad Sash

0.04 " Cladding

Al spacer

0.39

0.21

In spacer

0.29

0.13

0.08" Cladding

In spacer

0.31

0.17

The WINDOW 3.1 computer program [5] was used to determine the effects of these improvements in frame $U$-values on the overall $U$-value of a window utilizing 
insulated glass units with a center-of-glass U-value of $0.12 \mathrm{Btu} / \mathrm{hr}-\mathrm{ft}^{2}-\mathrm{F}$. Results are presented in Table 5.

\begin{tabular}{|c|c|c|}
\hline \multicolumn{3}{|c|}{$\begin{array}{l}\text { Table 5: Total Window U-Values (in Btu/hr-ft' }{ }^{2}-\mathrm{F} \text { ) } \\
\text { (Center-of-Glass U-values are } 0.12 \mathrm{Btu} / \mathrm{hr}-\mathrm{ft}^{2}-\mathrm{F} \text { ) }\end{array}$} \\
\hline Frame Descriptive & Frame U-value & U-value \\
\hline $\begin{array}{l}\text { conventional solid wood, } \\
\text { aluminum spacer }\end{array}$ & 0.36 & 0.23 \\
\hline $\begin{array}{l}\text { conventional solid wood, } \\
\text { insulated spacer }\end{array}$ & 0.26 & 0.17 \\
\hline $\begin{array}{l}\text { Vinyl Cladding }\left(0.08^{\prime \prime}\right) \\
\text { insulation filled, } \\
\text { insulated spacer }\end{array}$ & 0.14 & 0.13 \\
\hline $\begin{array}{l}\text { Jamb: } 50 \% \text { conductivity of wood, } \\
\text { Sash: } 10 \% \text { conductivity of wood, } \\
\text { insulated spacer }\end{array}$ & 0.10 & 0.13 \\
\hline
\end{tabular}

\section{Conclusions}

The findings presented in this paper indicate that the thermal performance of windows can be dramatically improved by changes in frame and sash design and material selection. While these findings are all based on the use of validated computer programs [6], we have only begun to experimentally verify the specific results presented in this paper.

Improvements in frame $U$-values (for the frame types modeled in this paper) can also be achieved by changing from an aluminum spacer to a lower conductivity spacer. This result has also been shown by Enermodal Engineering Ltd. [7].

Frame U-values can be greatly improved over today's standard wood frame with an aluminum spacer $\left(\mathrm{U}=0.36 \mathrm{Btu} / \mathrm{hr}-\mathrm{ft}^{2}-\mathrm{F}\right)$. A frame cunstructed of 0.08 inch thick vinyl skin, filled with an insulating material, and utilizing an insulating spacer has a predicted U-value of 0.14 , a $60 \%$ reduction. Such frames could be produced commercially today and are the subject of current modeling and testing. Similar reductions are possible with fiberglass-clad insulation-filled frames.

Sashes and frames built of solid material with conductivities significantly lower than that of wood also offer the potential for low U-value frames; however, no presently known materials meet these constraints and offer the structural and physical properties necessary for proper window frame construction. 
Future work involves the use of an infrared camera to validate the finite element models used in this paper and to evaluate the performance of prototype lowconductivity frames. Selected windows will also be tested to the validate total window U-values presented in Table 5.

\section{References}

1. Arasteh, D., Selkowitz, s., and Wolfe, J. 1989. "The Design and Testing of a Highly Insulating Glazing System for Use with Conventional Window Systems." Journal of Solar Energy Engineering, Transactions of the ASME, Vol 111. February.

[2] Arasteh, D., and Selkowitz, S., "A Superwindow Field Demonstration Program in Northwest Montana." Presented at the ASHRAE/DOE/BTECC/CIBSE Conference on Thermal Performance of the Exterior Envelopes of Buildings IV, Orlando, FL, Dec. 1989 and published in the Proceedings. Also published as Lawrence Berkeley Laboratory Report 26069; Berkeley, CA. September 1989.

[3] Arasteh, D., "An Analysis of Edge Heat Transfer in Residential Windows." Presented at the ASHRAE/DOE/BTECC/CIBSE Conference on Thermal

Performance of the Exterior Envelopes of Buildings IV, Orlando, FL, Dec. 1989 and published in the Proceedings. Also published as Lawrence Berkeley Laboratory Report 26068; Berkeley, CA. October 1989.

[4] DeSalvo, G.J., and Gorman, R.W. 1989. ANSYS Engineering Analysis System User's Manual; Version 4.4. Houston, PA: Swanson Analysis Systems.

[5] Lawrence Berkeley Laboratory, 1988. Windows and Daylighting Group. WINDOW 3.1 users and reference guide, Berkeley, CA.

[6]. Enermodal Engineering Limited, "The Effect of Frame Design on Window Heat Loss - Phase I," Report prepared for Energy, Mines and Resources Canada, DSS Contract File No. 23216-6-6253-SZ. Waterloo, Ontario.

[7]. Klems, J and Reilly, S. "Window Nighttime U-values: A Comparison between Computer Calculations and MoWiTT Measurements." ASHRAE Transactions, 1990.

\section{Acknowledgements}

This work was supported by the Assistant Secretary for Conservition and Renewable Energy, Office of Building Technologies, Building Systems and Materials Division of the U.S. Department of Energy under Contract No. DEAC03-76SF00098. Additional support was provided by the Residential Technology Section of the Bonneville Power Administration of the U.S. Department of Energy under Contract No. DE-AI79-86BP63401.

The authors wish to thank Manuel Acevedo-Ruiz at LBL for his assistance with this research project. 


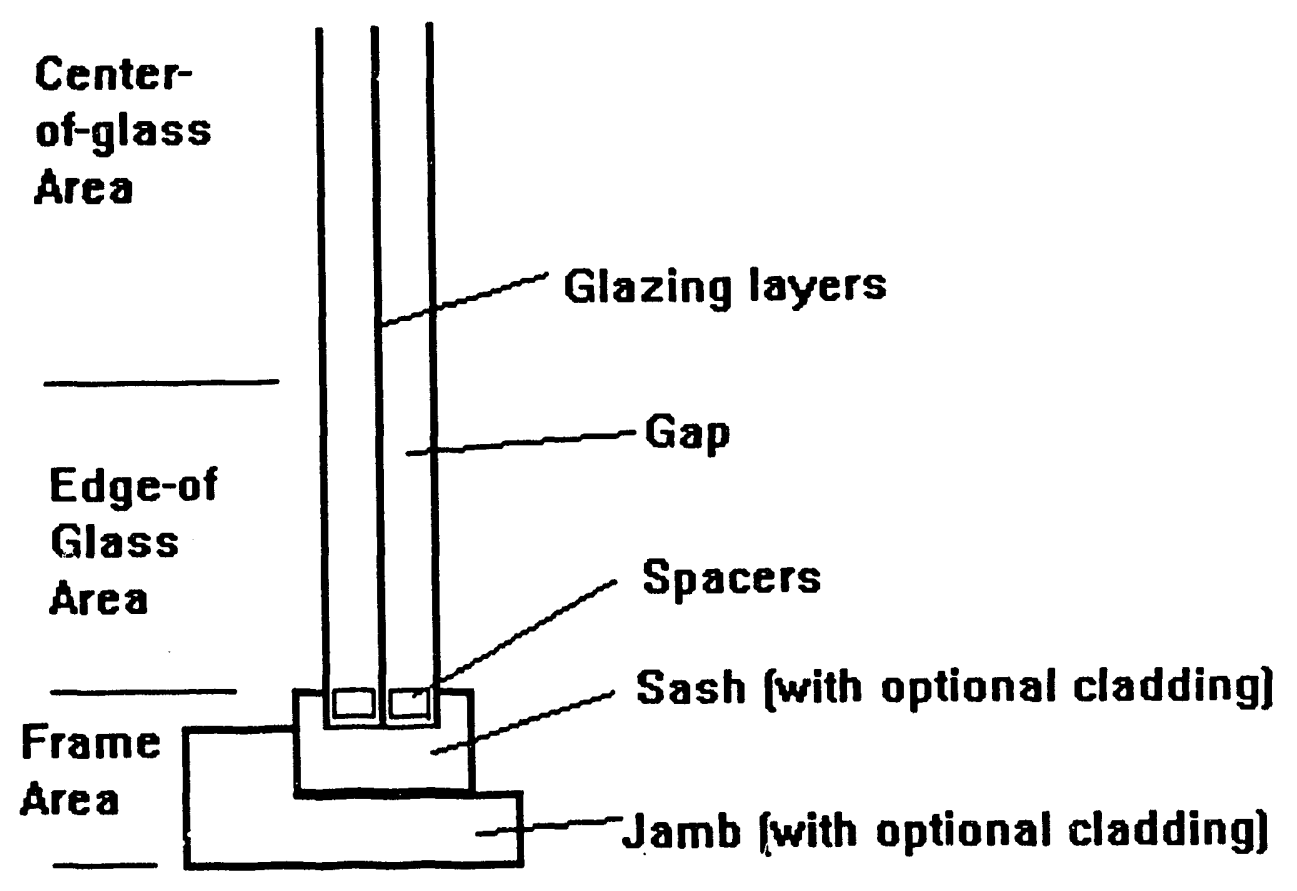

Figure 1: A cross-section of a superwindow. Three giazing layers are separated by two spacers. The glazings are coated with two low-emissivity coatings such that one coating faces each gap and the gaps are filled with a low-conductivity gas such as argon or krypton; such designs can result in center-of-glass U-values as low as 0.10 $\mathrm{Btu} / \mathrm{hr}-\mathrm{ft}^{2}-\mathrm{F}$. This insulated glass unit sits in the sash, which in turn, rests on the jamb. Heat transfer through the sash and jamb is normalized to the projected frame area and represe ited by the frame U-value. An edge-of-glass area and a corresponding edge-of-glass U-value is defined as that area within $2.5^{\prime \prime}$ of the frame/glass interface to account for the spacer's thermal bridging effects [3]. 


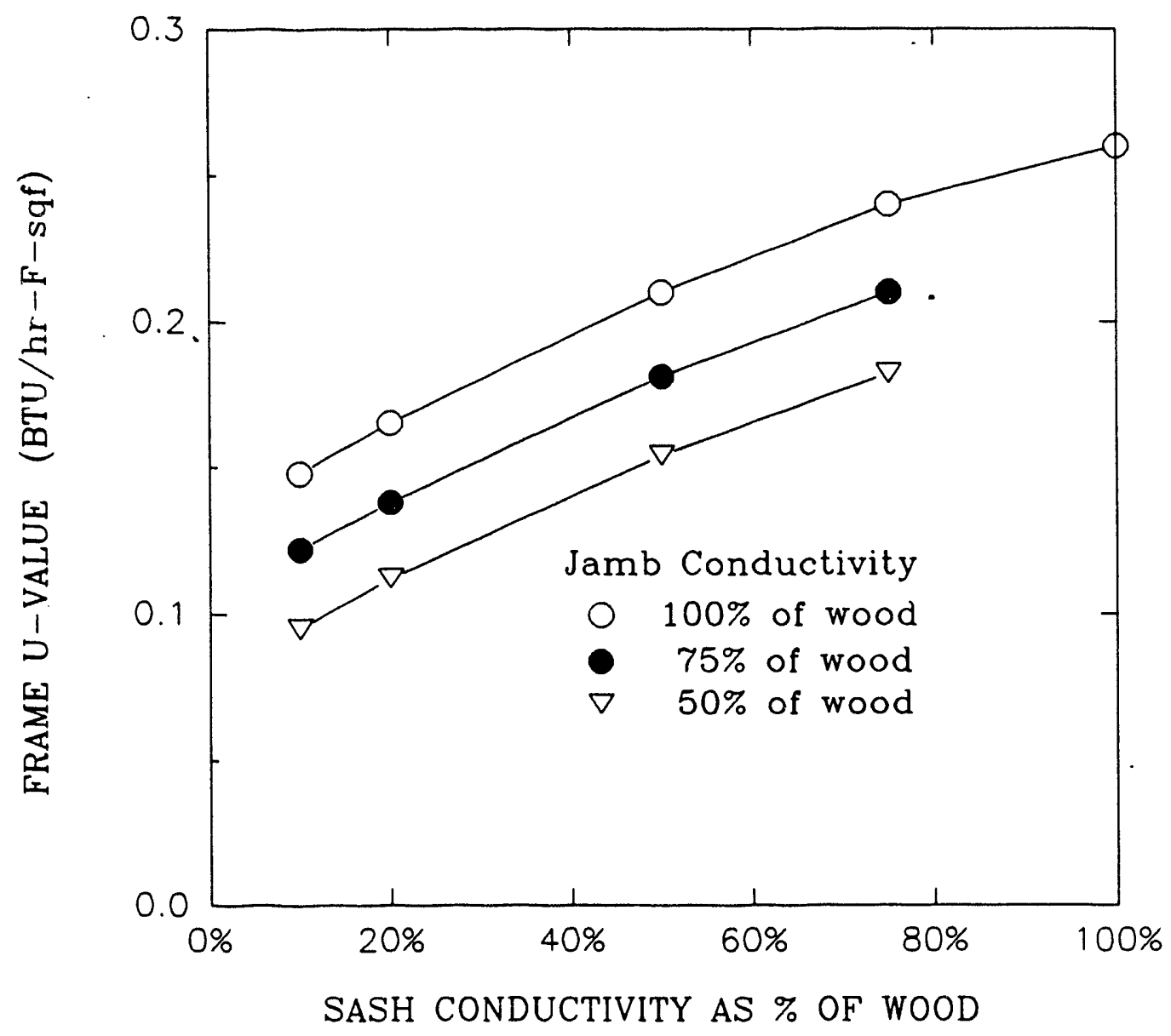

Figure 2: The effects of jamb and sash conductivity on frame U-values. 

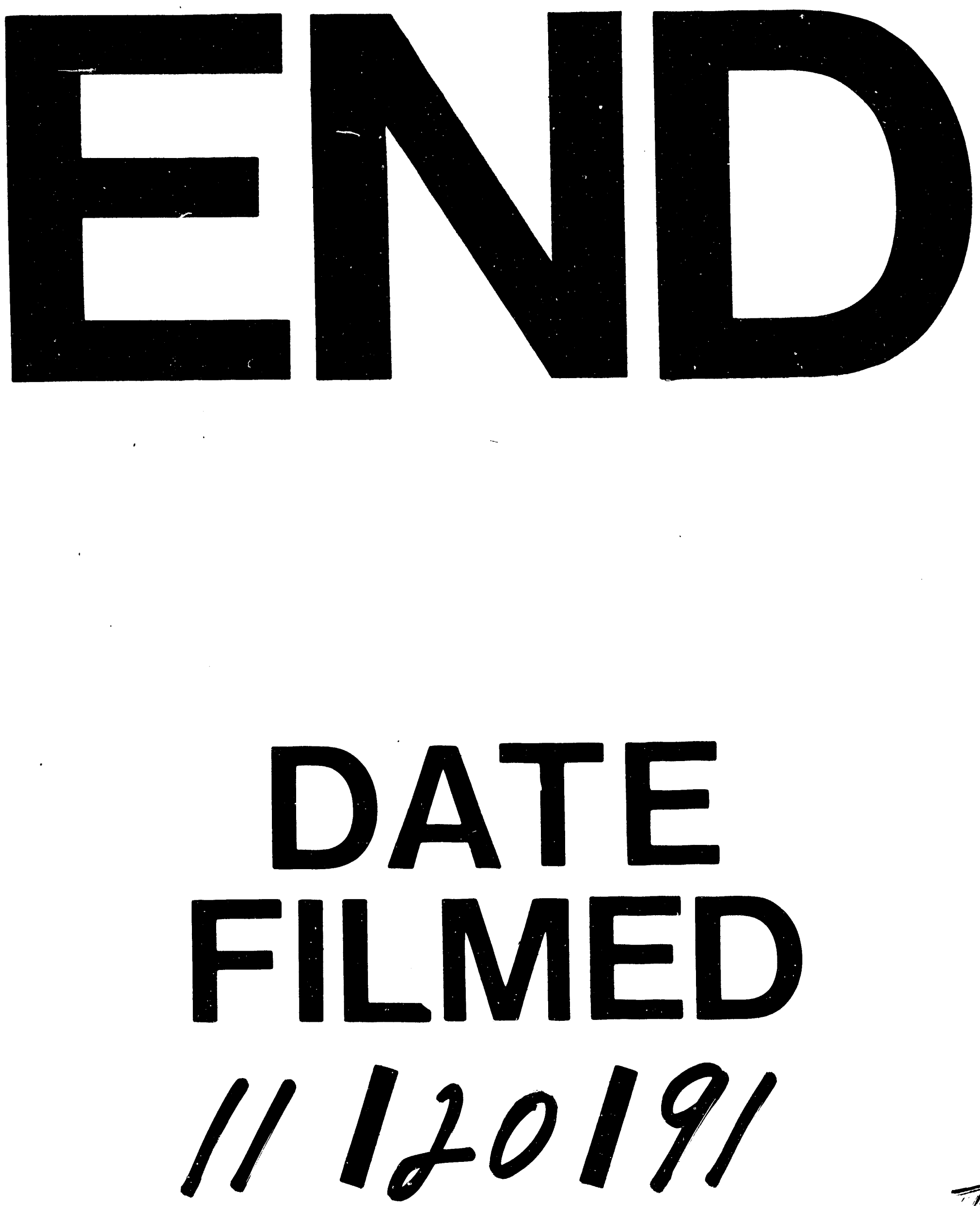

II 